\title{
Turnover and fractionation of nitrogen stable isotope in tissues of grass carp Ctenopharyngodon idellus
}

\author{
Bin Xia ${ }^{1}$, Qin-Feng Gao ${ }^{1, *}$, Haimei $\mathrm{Li}^{2}{ }^{2}$, Shuang-Lin Dong ${ }^{1}$, Fang Wang ${ }^{1}$ \\ ${ }^{1}$ Key Laboratory of Mariculture, Ministry of Education, Ocean University of China, Qingdao, Shandong 266003, China \\ ${ }^{2}$ College of Landscape Architecture and Forestry, Qingdao Agricultural University, Qingdao, Shandong 266003, China
}

\begin{abstract}
Determination of the isotopic turnover rate in the various tissues of an organism is one of the essential prerequisites for tracing the food sources of consumers and for elucidating trophic interactions in ecological studies using stable isotope analysis (SIA). Isotopic turnover and fractionation in the commercially important freshwater teleost grass carp Ctenopharyngodon idellus, however, are poorly understood so far. In the present study, we conducted a diet-switch experiment of C. idellus for 3 mo to assess nitrogen isotopic turnover and fractionation in different tissues of this species, including liver, muscle, and gill. The results revealed that turnover rates exhibited significant differences between tissues and increased in the sequence of gill < muscle < liver, owing to the differences in metabolic activities between the tissues. Contribution to longterm nitrogen isotopic turnover rates from metabolism was greatest for the liver ( 70 to $77 \%$ metabolic contribution) and greatest from growth for the gill (86 to $90 \%$ contribution of net tissue increase). Nitrogen half-lives estimated with time- or growth-based models were, respectively, $29.9 \mathrm{~d}$ and 1.18-fold mass increase for liver, $68.3 \mathrm{~d}$ and 1.45-fold mass increase for muscle, and $115.4 \mathrm{~d}$ and 1.81-fold mass increase for gill. The nitrogen isotopic fractionation of all tissues was enriched by 3 to $4 \%$ relative to the nitrogen isotopic signature of the diet, with significant differences between the 3 types of tissues, probably owing to the different biochemical pathways and constituents between the various tissues.
\end{abstract}

KEY WORDS: Ctenopharyngodon idellus · Nitrogen isotopic turnover · Metabolism $\cdot$ Growth Fractionation

Resale or republication not permitted without written consent of the publisher

\section{INTRODUCTION}

The stable isotope ratio of nitrogen, i.e. the ratio of ${ }^{15} \mathrm{~N}:{ }^{14} \mathrm{~N}\left(\delta^{15} \mathrm{~N}\right)$, is widely used for assessing the feeding ecology of organisms (Guelinckx et al. 2007, Overmyer et al. 2008) and the trophic interactions in food webs (Murchie \& Power 2004, Persaud et al. 2012). In contrast with traditional gut content analysis, which captures a snapshot of consumer food sources recently consumed (Jones \& Waldron 2003), stable isotope analysis (SIA) as a dietary tracer provides an integrated estimate of long-term food utilization (Gao et al. 2006, 2011) and reflects the iso- topic signature of diet sources with a fractionation factor by analyzing the entire organism or a specific tissue (Phillips \& Gregg 2003). In spite of the obvious advantages of SIA, multiple caveats or assumptions have been recognized and addressed for the application of SIA, such as the variable isotopic fractionation between various diet sources, consumer species, and tissue types, and the uptake and elimination kinetics of ${ }^{15} \mathrm{~N}$ and ${ }^{14} \mathrm{~N}$ in organisms after a diet switch (Gannes et al. 1997). Particularly, analysis of the nitrogen isotope ratio plays a more important role in elucidating trophic positions in ecological studies since nitrogen stable isotopes show more remarkable 
fractionation between trophic levels relative to carbon and sulfur (Post 2002).

After a consumer is provided with an isotopically distinct diet, the isotopic ratios of its tissues will change as a consequence of 2 general processes: catabolic breakdown and anabolic replacement. The isotopic turnover rate depends on both the growth rate, representing the synthesis from the new diet in excess of breakdown; and the metabolic rate, representing the balanced rate of breakdown of old tissue synthesized during feeding on a previous diet and resynthesis of tissue components made from the new diet (Hesslein et al. 1993, MacAvoy et al. 2005). With known growth rates, the proportional contributions of metabolism and growth to stable isotopic turnover can be estimated from nonlinear regressions of the isotopic turnover trajectories based on both time and growth models (Buchheister \& Latour 2010). Previous studies have showed that the contribution of metabolic replacement to the total isotopic turnover rate is negligible or of minor importance for the juveniles of ectothermic species, and growth is the primary factor driving the turnover of stable isotopes due to the low metabolic activities of ectothermic animals (Maruyama et al. 2001, Bosley et al. 2002, Tominaga et al. 2003). However, contrasting results have been recently found, showing that the isotopic turnover rate substantially varies depending on the relative metabolic activity of various tissues (Herzka \& Holt 2000, Herzka et al. 2001, Sakano et al. 2005, McIntyre \& Flecker 2006, Sulak et al. 2012).

With the increasing application of SIA in studies on trophic ecology, it is crucial to determine the extent and cause of the variation in isotopic turnover rates among species (Tieszen et al. 1983, Tarboush et al. 2006, Fisk et al. 2009) and tissues (MacNeil et al. 2006, Guelinckx et al. 2007), and to take tissuespecific turnover rates into account for accurate interpretation of isotopic data. Meanwhile, the time lag determined by the isotopic turnover rate in the tissue is essential for quantitatively analyzing shifts in food habit and habitat. Although research on isotopic turnover rates in organisms has become more popular recently, studies focusing on the nitrogen isotopic turnover rate in various fish tissues after a diet switch are very scarce, especially for slow-growing fish (Vander Zanden et al. 1998, Reich et al. 2008).

When in equilibrium with the new diet after food conditions are changed, fractionation represents the difference in stable isotopic ratios between the diet and the tissue of the consumer, which is strongly related to metabolic processes (Fry 2006). Generally, $\delta^{15} \mathrm{~N}$ of the consumer is slightly higher than that in its diet because the preference for the lighter isotope in enzymatic processes leads to more excretion of isotopically lighter ${ }^{14} \mathrm{~N}$ relative to ${ }^{15} \mathrm{~N}$, and the heavy nitrogen isotope remains in the tissues of the consumer. Consequently, the ratio of ${ }^{15} \mathrm{~N}:{ }^{14} \mathrm{~N}\left(\delta^{15} \mathrm{~N}\right)$ will increase in the consumer. Traditional fractionation of 2.0 to $3.4 \%$ for nitrogen per trophic level has been applied in aquatic systems (Peterson \& Fry 1987, Karlsson et al. 2004). However, broad bounds of fractionations have been reported $\left(\delta^{15} \mathrm{~N},-0.7\right.$ to $9.2 \%$ ), and considerable differences in fractionation values have been observed among species and tissues (Pinnegar \& Polunin 1999, Vanderklift \& Ponsard 2003, Buchheister \& Latour 2010, Sulak et al. 2012). Taking species- or tissue-specific fractionation into account can greatly improve the accuracy when predicting trophic levels or stable isotopic signatures of organisms based on known isotopic data. It is essential to measure fractionation, since only a few fractionation values for fish tissues have been published.

Grass carp Ctenopharyngodon idellus is the most commercially important freshwater fish species for aquaculture in China. Its production has increased rapidly over recent decades. At present, the production of this species has reached 4222000 tons, or $18.0 \%$ of the total aquaculture production of all freshwater fish species in China (MOAC 2011). In spite of the fast-growing aquaculture industry, application of stable isotopes for biological and ecological studies on this species has not been reported so far. In the present study, we conducted a diet-switch experiment where grass carp were fed an isotopically distinct diet, and changes in nitrogen stable isotope values were recorded over time until fish tissues came to reflect the nitrogen isotopic signatures of the new diet. The objectives were: (1) to determine turnover rate and fractionation of nitrogen stable isotope in muscle, liver, and gill of C. idellus, and (2) to examine and compare the proportional contributions of metabolism and growth to nitrogen stable isotopic turnover in these 3 tissues.

\section{MATERIALS AND METHODS}

\section{Experiment}

The experiment was conducted at the Fresh Water Fishery Research Institute of Shandong Province, China $\left(36^{\circ} 69^{\prime} \mathrm{N}, 116^{\circ} 86^{\prime} \mathrm{E}\right)$ and lasted for 3 mo. Grass carp were collected from a local commercial farm. They were continuously fed artificial feed (control feed) with constant nitrogen stable isotopic com- 
position to ensure the complete turnover of the stable isotopes and thus equal isotopic ratios for grass carp individuals at the start of experiment. The grass carp were transported to the laboratory immediately after collection and acclimated for $3 \mathrm{wk}$ while maintained with the control feed. After acclimation, the grass carp were divided into 2 groups. The first group (control group) was fed the control feed continuously, which had a nitrogen stable isotopic ratio of $2.04 \pm$ $0.06 \%$ and dietary components of $28.1 \%$ protein, $6.3 \%$ crude fat, and $3.2 \%$ fiber. The second group (experimental group) was for the diet-switch experiment and was fed pelletized feed (experimental feed) whose main ingredient was ground corn. The nitrogen stable isotopic ratio of the experimental feed $(6.68 \pm 0.17 \%)$ was distinct from that of the control feed $(2.04 \pm 0.06 \%)$. This allowed the identification of the changes in the stable isotopic ratios in the experimental group after the diet switch. The major components of the experimental feed included $9.2 \%$ protein, $3.1 \%$ crude fat, and $5.5 \%$ fiber. Each group contained 90 grass carp randomly allocated into 3 cylindrical aquaria as triplicates, i.e. 30 individuals were cultured in each aquarium. The average initial wet weight of the grass carp was not statistically different among the aquaria (ANOVA, $p>0.05$ ).

During the experiment, grass carp were fed a daily ration of $5 \%$ body weight and kept in freshwater aquaria at a temperature of $20 \pm 0.5^{\circ} \mathrm{C}$ and a $13 \mathrm{~h}$ light: $11 \mathrm{~h}$ dark photoperiod. Adequate water circulation and continuous aeration ensured homogeneous and stable environmental conditions for each aquarium.

At the start of the experiment, 3 fish were sacrificed to obtain baseline nitrogen isotopic signatures of liver, muscle, and gill. To monitor the nitrogen isotopic turnover rates of the fish tissues over the duration of the experiment, 3 individuals from the same aquaria in each group were randomly sampled on Days 7, 14, $28,42,56$, and 84 , and euthanized by low-temperature anesthesia for measurement of wet weight and nitrogen stable isotopes.

Wet weight was determined to the nearest $0.01 \mathrm{~g}$ using an electronic balance. The specific growth rate (SGR) and the relative increase in weight were calculated as described in Eq. (3). After mass weighing, the collected grass carp were dissected; liver, trunk muscle, and gill arch were separated and immediately rinsed with distilled double deionized water. All samples for SIA were dried at $60^{\circ} \mathrm{C}$ for over $72 \mathrm{~h}$ to constant dry weight. Tissues of 3 individuals sampled from the same aquarium were pooled as 1 replicate. The dried tissues were ground to fine, homogeneous powder using a micro-grinder and a sieve of $0.5 \mathrm{~mm}$ mesh size. Tissues collected from the 3 different aquaria were used as 3 replicates. The tissue powder was tightly sealed in a glass Petri dish and stored in an ultra-low-temperature freezer $\left(-80^{\circ} \mathrm{C}\right)$ for future analyses.

\section{Stable isotope analysis}

After the sample homogenization, nitrogen isotope ratios were determined using an elemental analyzer coupled with an isotope ratio mass spectrometer (EA-IRMS, ThermoFinnigan MAT Delta-plus). Results of isotope ratios were expressed in standard $\delta$-unit notation, which is defined as follows:

$$
\delta X=\left[\left(R_{\text {sample }} / R_{\text {standard }}\right)-1\right] \times 1000 \%
$$

where $X={ }^{15} \mathrm{~N}$, and $R$ is the ${ }^{15} \mathrm{~N}:{ }^{14} \mathrm{~N}$ ratio. The values were reported relative to air $\mathrm{N}_{2}$. A laboratory working standard (glycine) was run for every 10 samples. Analytical precision was $\pm 0.1 \%$.

\section{Time-based model}

To estimate the turnover rates in different tissues of grass carp, changes in nitrogen stable isotope ratios were modeled as an exponential function of time including growth and metabolic constants after the diet switch (Hesslein et al. 1993). The time-based model is described by the following equation:

$$
\delta_{t}=\delta_{\mathrm{f}}+\left(\delta_{\mathrm{i}}-\delta_{\mathrm{f}}\right) \mathrm{e}^{-(k+m) t}
$$

where $\delta_{t}$ is the $\delta^{15} \mathrm{~N}$ value of fish at experimental time $t, \delta_{\mathrm{f}}$ is the expected isotopic value for grass carp in equilibrium with the new diet, $\delta_{\mathrm{i}}$ is the initial $\delta^{15} \mathrm{~N}$ prior to the diet switch, and $m$ is the metabolic turnover constant. $\delta_{\mathrm{f}}$ was estimated using nonlinear regression, and the average isotopic ratios of the 3 grass carp collected before the diet switch was used as the estimate of $\delta_{\mathrm{i}}$ in the model. The growth rate constant $k$, represented by SGR, was determined by the following exponential growth model (Sun et al. 2012):

$$
k=\ln \left(W_{\mathrm{f}} / W_{\mathrm{i}}\right) / t
$$

where $W_{\mathrm{i}}$ is the initial weight of grass carp on Day 0 , and $W_{\mathrm{f}}$ is the final weight when sampled on Day $t$. Any nitrogen isotopic turnover in excess of growth was attributable to metabolic tissue replacement $(m)$. $m$ was derived by fitting the exponential model in Eq. (2) using the software SPSS for Windows, Release 16.0 (SPSS Inc. 2008), to match the observed isotopic 
data, i.e. using the experimental time $(t)$ as independent, and the corresponding $\delta^{15} \mathrm{~N}$ values of fish at Time $t\left(\delta_{t}\right)$ as dependent. Expected nitrogen isotopic change due to growth alone was calculated using Eq. (2) where $m$ was set to 0 (Hesslein et al. 1993). The relative contributions of growth $(k)$ and metabolism $(m)$ were calculated as the ratio of each parameter to the sum of the 2 parameters $(k+m)$. Such calculation yielded the contributing proportions of growth $\left(P_{\mathrm{g}}\right)$ and metabolism $\left(P_{\mathrm{m}}\right)$ to the turnover of nitrogen stable isotope.

Fractionation estimates of $\delta^{15} \mathrm{~N}$ between the diet and each tissue $(\Delta)$ were calculated as

$$
\Delta=\delta_{\mathrm{f}}-\delta_{\mathrm{d}}
$$

(Minagawa \& Wada 1984), where $\delta_{\mathrm{d}}$ is the $\delta^{15} \mathrm{~N}$ of the experimental feed after the diet switch. The time period needed to achieve an $\alpha$ percent turnover of $\delta^{15} \mathrm{~N}$ was calculated as

$$
T_{\alpha / 100}=-\ln (1-\alpha / 100) /(k+m)
$$

(Tieszen et al. 1983). To determine half-life $\left(T_{0.5}\right)$ of tissue turnover, the equation is solved for $\alpha=50 \%$.

\section{Growth-based model}

Changes in nitrogen stable isotope ratios were also modeled as a function of relative growth after the diet switch. The growth-based model was represented by

$$
\delta_{W_{\mathrm{R}}}=\delta_{\mathrm{f}}+\left(\delta_{\mathrm{i}}-\delta_{\mathrm{f}}\right) W_{\mathrm{R}}^{c}
$$

(Buchheister \& Latour 2010), where $\delta_{\mathrm{i}}$ and $\delta_{\mathrm{f}}$ are the initial and final nitrogen stable isotope ratios of the grass carp, respectively, as previously defined for Eq. (2). The relative increase in weight of grass carp $\left(W_{\mathrm{R}}\right)$ was calculated as the final wet weight divided by the initial wet weight, and the variable $\delta_{W_{R}}$ is the measured isotopic value for a fish given its increase in weight. $C$ is the turnover rate constant and was derived by fitting the exponential model in Eq. (6) using SPSS for Windows, Release 16.0 (SPSS Inc. 2008), to match the observed isotopic data, i.e. using the relative mass increase $W_{\mathrm{R}}$ as independent, and the $\delta^{15} \mathrm{~N}$ values corresponding to the $W_{\mathrm{R}}\left(\delta_{W_{\mathrm{R}}}\right)$ as dependent. In the growth-based model, if $c=-1$, growth is entirely responsible for turnover, whereas if $c<-1$, metabolism is contributing to turnover of the stable isotope in the tissue, with more negative values representing greater contributions by metabolism.

Diet-tissue fractionations $(\Delta)$ were also derived from the estimates of $\delta_{\mathrm{f}}$ according to the growth- based model using Eq. (4). The amount of relative growth needed to achieve an $\alpha$ percent turnover of $\delta^{15} \mathrm{~N}$ was calculated as

$$
G_{\alpha / 100}=\mathrm{e}^{\ln (1-\alpha / 100) / c}
$$

The growth-based half-life $\left(G_{0.5}\right)$ is solved for $\alpha=$ $50 \%$ and represents the amount of growth needed for a $50 \%$ conversion between the initial and final isotopic values. Hence, the half-life estimated with the growth-based model is expressed as an $x$-fold mass increase. The fractions of new tissue derived from growth $\left(D_{\mathrm{g}}\right)$ and from metabolism $\left(D_{\mathrm{m}}\right)$ were calculated at the midpoint between the old and new isotopic values:

$$
\begin{aligned}
& D_{\mathrm{g}}=2\left(G_{0.5}-1\right) / G_{0.5} \\
& D_{\mathrm{m}}=\left(2-G_{0.5}\right) / G_{0.5}
\end{aligned}
$$

\section{Statistical analysis}

Differences in the nitrogen isotopic ratios of the grass carp tissues between the control and experimental groups were compared using paired Student's $t$-test paired by sampling time. Differences in the isotopic ratios between the sampling time points and between the 3 types of tissue, i.e. liver, muscle, and gill, were analyzed using 2-way ANOVA with the sampling time points and tissue types as 2 treatment factors, followed by Tukey's test for multiple comparisons. Regression analyses were applied using nonlinear procedures to determine the relationships of $\delta^{15} \mathrm{~N}$ values to the SGR $(k)$ and metabolic rate constant $m$ for the time-based model, and to the relative growth $W_{\mathrm{R}}$ for the growth-based model. Prior to statistical analysis, raw data were diagnosed for normality of distribution and homogeneity of variance with the Kolmogorov-Smirnov test and Levene's test, respectively (Zar 1999). All statistical analyses were performed with SPSS for Windows, Release 16.0 (SPSS Inc. 2008).

\section{RESULTS}

\section{Growth}

All grass carp individuals in the control and experimental groups showed obvious growth during the experiment (ANOVA, p < 0.05), and no significant difference was found in the final body weight of the fish between the control and experimental groups (ANOVA, $\mathrm{p}>0.05$ ). Individuals in the experimental group increased 1.58 times relative to the initial 
Table 1. Ctenopharyngodon idellus. Temporal changes in average wet weight, specific growth rate (SGR), and relative growth ( $W_{\mathrm{R} i}$ final wet weight divided by initial wet weight) of grass carp in the experimental group. Data are mean \pm SD. Numbers with different superscripted letters mean a significant difference $(p<0.05)$. na: not applicable

\begin{tabular}{|lccc|}
\hline Day & Wet weight $(g)$ & SGR $\left(\mathrm{d}^{-1}\right)$ & $W_{\mathrm{R}}$ \\
\hline 0 & $52.70 \pm 0.70^{\mathrm{a}}$ & na & na \\
7 & $55.05 \pm 0.17^{\mathrm{ab}}$ & $0.0062 \pm 0.0018$ & $1.04 \pm 0.01$ \\
14 & $56.90 \pm 1.75^{\mathrm{ab}}$ & $0.0055 \pm 0.0026$ & $1.08 \pm 0.04$ \\
28 & $60.99 \pm 1.31^{\mathrm{bc}}$ & $0.0052 \pm 0.0005$ & $1.16 \pm 0.02$ \\
42 & $66.14 \pm 1.61^{\mathrm{cd}}$ & $0.0054 \pm 0.0005$ & $1.26 \pm 0.03$ \\
56 & $71.68 \pm 4.44^{\mathrm{d}}$ & $0.0055 \pm 0.0012$ & $1.36 \pm 0.10$ \\
84 & $83.41 \pm 7.17^{\mathrm{e}}$ & $0.0054 \pm 0.0010$ & $1.58 \pm 0.13$ \\
\hline
\end{tabular}

weight and reached a wet weight of $83.41 \mathrm{~g}$ on average after the $84 \mathrm{~d}$ experiment (Table 1). SGR showed the highest value of $0.0062 \mathrm{~d}^{-1}$ over the first $7 \mathrm{~d}$, and stayed relatively constant afterward, with a range between 0.0052 and $0.0055 \mathrm{~d}^{-1}$.

\section{Temporal changes in $\delta^{15} \mathbf{N}$}

Temporal changes in the observed $\delta^{15} \mathrm{~N}$ values for liver, muscle, and gill in the control and experimental groups are shown in Fig. 1. Grass carp exhibited nonsignificant differences in the initial $\delta^{15} \mathrm{~N}$ values among all groups. Throughout the experiment, no significant changes in the $\delta^{15} \mathrm{~N}$ values occurred between the sampling time points or between the 3 types of tissues in the control group (ANOVA, p > 0.05). In contrast, for the experimental group, the observed $\delta^{15} \mathrm{~N}$ values of the 3 types of fish tissues gradually increased after the diet switch owing to the assimilation of the experimental feed, which has a higher $\delta^{15} \mathrm{~N}$ value relative to the control feed. For all tissues, significant nitrogen isotopic shifts were observed on Day 7 relative to the initial nitrogen isotopic composition, and such shifts continued throughout the experiment (ANOVA, p < 0.05). Significant differentiation in the isotopic ratios between the 3 types of tissues commenced from the first week, and the $\delta^{15} \mathrm{~N}$ values increased in the sequence of gill < muscle < liver (Fig. 1).

\section{Contributions of growth and metabolism to $\delta^{15} \mathrm{~N}$ turnover}

The expected changes in the nitrogen stable isotope ratios for liver, muscle, and gill estimated with the time- and growth-based models are illustrated in

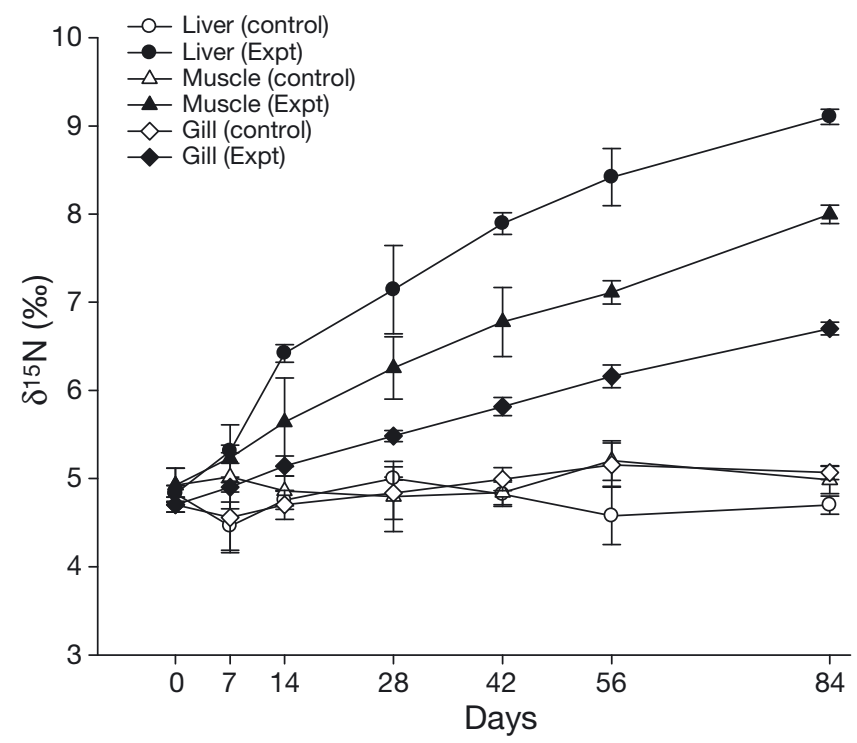

Fig. 1. Ctenopharyngodon idellus. Temporal changes (mean $\pm \mathrm{SD}$ ) in observed $\delta^{15} \mathrm{~N}$ values for grass carp liver, muscle, and gill tissue

Figs. 2 \& 3, respectively. For all 3 types of tissues, the nitrogen isotopic turnover rates with contributions of growth plus metabolism (solid lines) were significantly higher than those owing to growth alone (dotted lines) based on either the time (Fig. 2) or growth model (Fig. 3), suggesting that growth was not solely responsible for nitrogen isotopic turnover. For the time-based model (Table 2), the nitrogen isotopic turnover rates driven by both growth and metabolism $(k+m)$ varied substantially between tissues (ANOVA, $\mathrm{p}<0.05)$, with the highest value of $0.0241 \mathrm{~d}^{-1}$ for liver and the lowest value of $0.0061 \mathrm{~d}^{-1}$ for gill, showing that nitrogen turned over most rapidly in liver, followed by muscle and then gill. In addition, the proportional contribution of metabolism to nitrogen turnover $\left(P_{\mathrm{m}}\right)$ suggested that metabolic tissue replacement accounted for $77 \%$ of nitrogen turnover for liver, $47 \%$ for muscle, and $14 \%$ for gill, suggesting that the change in the $\delta^{15} \mathrm{~N}$ value of liver was principally derived from metabolic tissue replacement, while for gill, the isotopic turnover was primarily driven by the growth-related process of dilution (Table 2). As for the growth-based model (Table 3), the most negative value of $c=-4.4900$ confirmed the predominant role of metabolism in $\delta^{15} \mathrm{~N}$ turnover of liver. The growth-based model, however, generated slightly lower estimates of metabolic contributions to isotopic turnover for all 3 types of tissue relative to the results from the time-based model, with $D_{\mathrm{m}}$ values of $70 \%, 39 \%$, and $10 \%$ for liver, muscle, and gill, respectively (Table 3 ). 


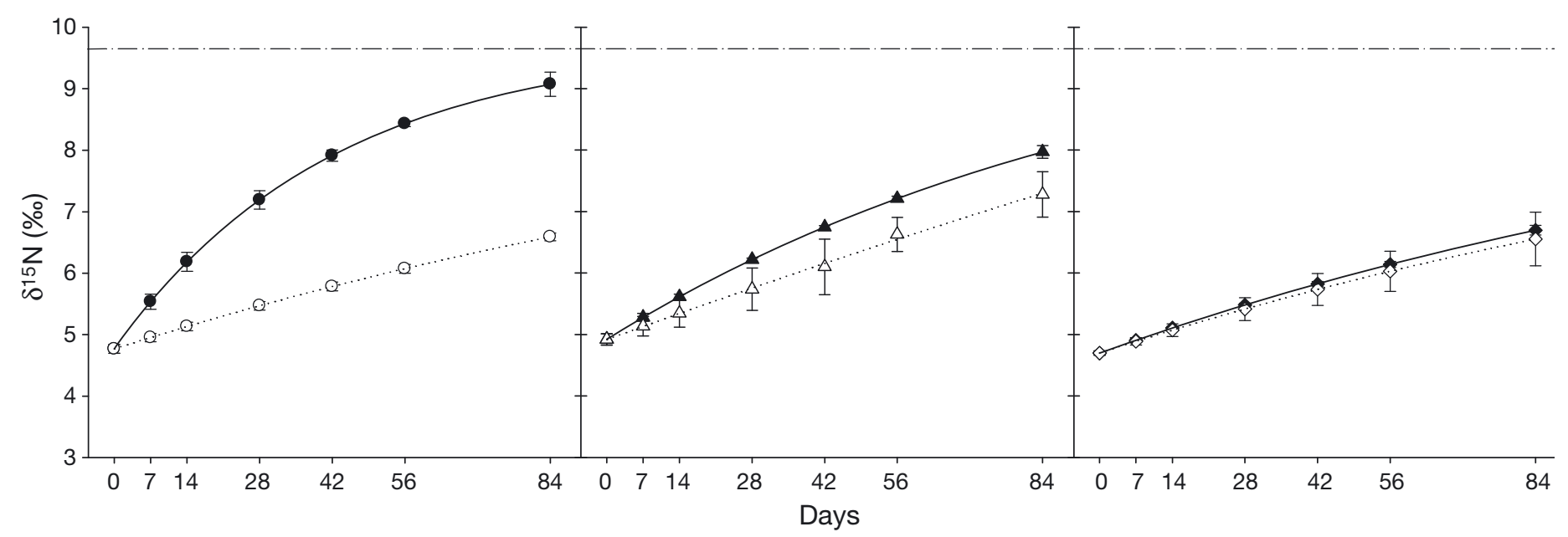

Fig. 2. Ctenopharyngodon idellus. Changes in $\delta^{15} \mathrm{~N}$ values (mean $\pm \mathrm{SD}$ ) estimated with the time-based model for liver (left), muscle (middle), and gill (right) tissue. Solid lines/filled symbols represent the $\delta^{15} \mathrm{~N}$ values with the contribution of growth and metabolism, and dotted lines/open symbols are the $\delta^{15} \mathrm{~N}$ values with the contribution of growth alone $(m=0)$. The horizontal dash-dotted lines represent the expected final $\delta^{15} \mathrm{~N}$ values of the grass carp tissues in equilibrium with experimental feed

\section{Turnover half-life and fractionation of nitrogen stable isotopes}

For the time-based model using Eq. (5), half-life was 29.9, 68.3, and $115.4 \mathrm{~d}$ for liver, muscle, and gill, respectively. To attain $95 \%$ of ${ }^{15} \mathrm{~N}$ turnover, 129.4 , 295.3, and $498.5 \mathrm{~d}$ were required for liver, muscle, and gill, respectively (Table 2). Results estimated with the growth-based model (Eq. 7) showed that grass carp achieved $50 \%$ turnover in liver, muscle, and gill when growing 1.18, 1.45, and 1.81 times relative to their initial mass, respectively. The $95 \%$ turnover of ${ }^{15} \mathrm{~N}$ for liver occurred after an approxi- mately double increase in mass, whereas 5.14- and 13.39-fold increase in mass were required for muscle and gill, respectively (Table 3 ).

Based on the time model, the expected $\delta^{15} \mathrm{~N}$ values of the grass carp in the status of complete equilibrium with the experimental feed $\left(\delta_{\mathrm{f}}\right)$ were $9.83 \%, 10.63 \%$, and $9.75 \%$ for liver, muscle, and gill, respectively (Table 2). The $\delta_{\mathrm{f}}$ values derived from the growthbased model were $9.80 \%$, $10.57 \%$, and $9.72 \%$ for liver, muscle, and gill, respectively, which were not significantly different from those from the time-based model (ANOVA, p > 0.05). The nitrogen isotopic fractionations showed significant differences between

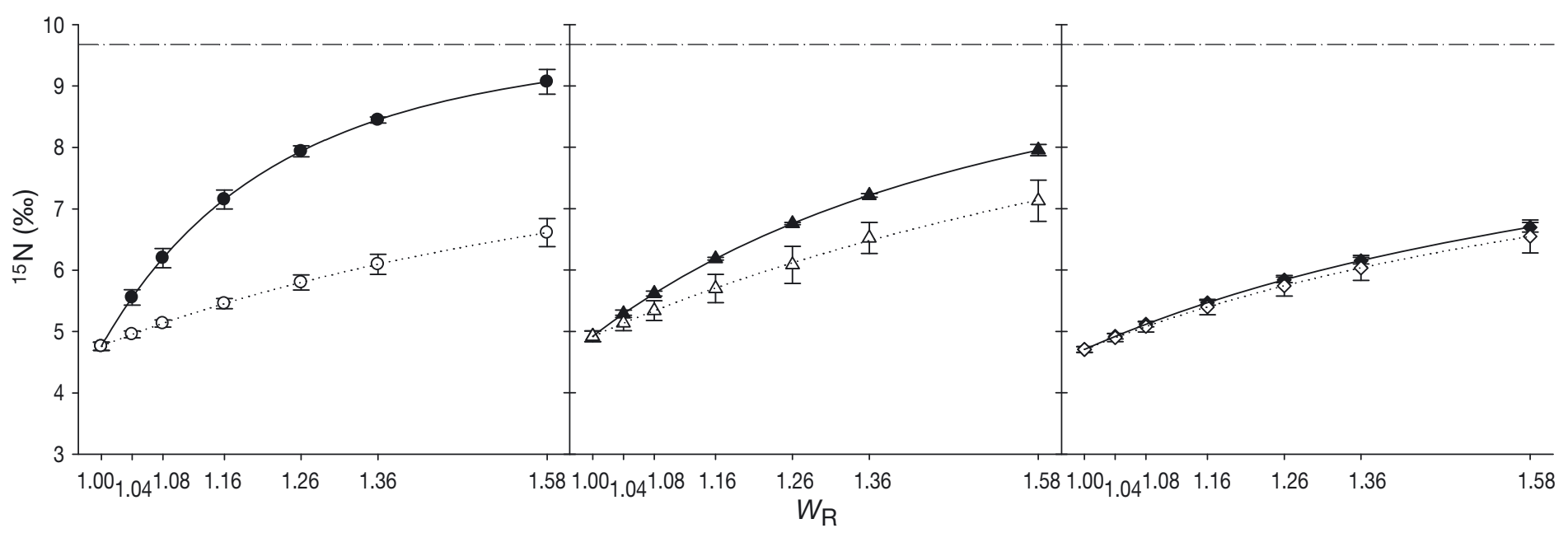

Fig. 3. Ctenopharyngodon idellus. Changes in $\delta^{15} \mathrm{~N}$ values (mean $\pm \mathrm{SD}$ ) estimated with the growth-based model for liver (left), muscle (middle), and gill (right) tissue. $W_{\mathrm{R}}$, relative growth (final wet weight divided by initial wet weight). Solid lines/filled symbols represent the $\delta^{15} \mathrm{~N}$ values with the contribution of growth and metabolism, and dotted lines/open symbols are the $\delta^{15} \mathrm{~N}$ values with the contribution of growth alone $(c=-1)$. The horizontal dash-dotted lines represent the expected final $\delta^{15} \mathrm{~N}$ values of the grass carp tissues in equilibrium with experimental feed 
Table 2. Ctenopharyngodon idellus. Parameter estimates and calculations (mean $\pm \mathrm{SD}$ ) from the time-based model of $\delta^{15} \mathrm{~N}$

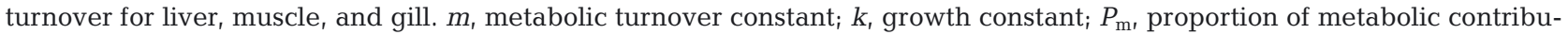
tion to nitrogen turnover; $P_{\mathrm{g}}$, proportion of growth contribution to nitrogen turnover; $T_{0.5}$, time-based half-life; $T_{0.95}$, time needed to reach $95 \%$ nitrogen turnover; $\delta_{\mathrm{f}}$, final asymptotic $\delta^{15} \mathrm{~N}$ value; and $\Delta$, fractionation between experimental feed and fish tissue

\begin{tabular}{|lcccccccc}
\hline Tissue & $m\left(\mathrm{~d}^{-1}\right)$ & $k+m\left(\mathrm{~d}^{-1}\right)$ & $P_{\mathrm{m}}$ & $P_{\mathrm{g}}$ & $T_{0.5}(\mathrm{~d})$ & $T_{0.95}(\mathrm{~d})$ & $\delta_{\mathrm{f}}(\%)$ & $\Delta(\%)$ \\
\hline Liver & $0.0187 \pm 0.0048$ & $0.0241 \pm 0.0057$ & $0.77 \pm 0.02$ & $0.23 \pm 0.02$ & $29.9 \pm 7.7$ & $129.4 \pm 33.3$ & $9.83 \pm 0.67$ & $3.14 \pm 0.80$ \\
Muscle & $0.0041 \pm 0.0032$ & $0.0096 \pm 0.0025$ & $0.47 \pm 0.15$ & $0.53 \pm 0.15$ & $68.3 \pm 9.1$ & $295.3 \pm 39.4$ & $10.63 \pm 1.17$ & $3.95 \pm 1.20$ \\
Gill & $0.0009 \pm 0.0009$ & $0.0061 \pm 0.0007$ & $0.14 \pm 0.15$ & $0.86 \pm 0.15$ & $115.4 \pm 14.0$ & $498.5 \pm 60.5$ & $9.75 \pm 0.64$ & $3.06 \pm 0.48$ \\
\hline
\end{tabular}

Table 3. Ctenopharyngodon idellus. Parameter estimates and calculations (mean $\pm \mathrm{SD}$ ) from the growth-based model of $\delta^{15} \mathrm{~N}$ turnover for liver, muscle, and gill. $C$, turnover constant; $D_{\mathrm{m}}$, proportion of metabolic contribution to nitrogen turnover; $D_{\mathrm{g}}$, proportion of growth contribution to nitrogen turnover; $G_{0.5}$, growth-based half-life ( $x$-fold increase); $G_{0.95}$, amount of relative growth needed to reach $95 \%$ nitrogen turnover ( $x$-fold increase); $\delta_{\mathrm{f}}$, final asymptotic $\delta^{15} \mathrm{~N}$ value; and $\Delta$, fractionation between experimental feed and fish tissue

\begin{tabular}{|lccccrrr|}
\hline Tissue & \multicolumn{1}{c}{$c$} & $D_{\mathrm{m}}$ & $D_{\mathrm{g}}$ & $G_{0.5}$ & \multicolumn{1}{c|}{$G_{0.95}$} & \multicolumn{1}{c}{$\delta_{\mathrm{f}}(\%)$} & $\Delta(\%)$ \\
\hline Liver & $-4.4900 \pm 1.0803$ & $0.70 \pm 0.07$ & $0.30 \pm 0.07$ & $1.18 \pm 0.05$ & $2.03 \pm 0.38$ & $9.80 \pm 0.67$ & $3.12 \pm 0.80$ \\
Muscle & $-1.7766 \pm 0.4595$ & $0.39 \pm 0.07$ & $0.61 \pm 0.07$ & $1.45 \pm 0.07$ & $5.14 \pm 1.25$ & $10.57 \pm 1.16$ & $3.88 \pm 1.19$ \\
Gill & $-1.1209 \pm 0.1453$ & $0.10 \pm 0.04$ & $0.90 \pm 0.04$ & $1.81 \pm 0.07$ & $13.39 \pm 2.32$ & $9.72 \pm 0.66$ & $3.03 \pm 0.51$ \\
\hline
\end{tabular}

tissues (ANOVA, p < 0.05). The fractionations for each specific tissue were consistent between the 2 models (ANOVA, p > 0.05), with the highest fractionation seen in muscle $(\Delta=3.95 \%$ and $3.88 \%$ or timeand growth-based models, respectively). Nitrogen fractionations for liver and gill ranged, depending on whether the growth- or time-based model was used, from 3.12 to $3.14 \%$ and from 3.03 to $3.06 \%$, respectively (Tables $2 \& 3$ ).

\section{DISCUSSION}

As an efficient trophic marker, nitrogen SIA is widely used for diagnosing trophic relationships in aquatic ecosystems (McCutchan et al. 2003, Vanderklift \& Ponsard 2003, McIntyre \& Flecker 2006). Generally, such studies are based on 2 assumptions: (1) consumers are in isotopic equilibrium with their diets; and (2) fractionations between the diet and the consumer's tissue are known (Post 2002). However, owing to various biological and environmental factors, such as the seasonality of food availability, the variable isotopic signatures of a single diet over space and time, the movement or migration of predators, and the physiological characteristics of various species, the assumption that an organism is isotopically equilibrated to the diet are frequently violated (Sakano et al. 2005, Sweeting et al. 2007). Therefore, there is a high demand to carry out laboratory experiments under controlled conditions for determining the turnover rate of isotopes, especially for unstudied species and tissues (Fisk et al. 2009). Previous studies have been mainly focused on endotherms, such as mammals and birds (Hobson et al. 2000, MacAvoy et al. 2005), whereas ectotherms, especially fish tissues, have rarely been addressed so far (Hesslein et al. 1993, Harvey et al. 2002, MacNeil et al. 2005, Suring \& Wing 2009, Sulak et al. 2012).

In the present study, the nitrogen stable isotope turnover was analyzed for 3 types of grass carp tissue by means of a diet-switch study. The results showed that the nitrogen isotopic signatures of grass carp tissue reflected and approached those of the new diet (experimental feed), and the nitrogen isotopic turnover processes were mathematically predictable following the turnover models, as reported by others (Guelinckx et al. 2007). Hesslein et al. (1993) reported that turnover rates of nitrogen stable isotope for liver and muscle tissue were similar in broad whitefish, suggesting that the remarkable differences in turnover rates between tissues of endotherms might not occur in fishes (Sweeting et al. 2005, McIntyre \& Flecker 2006). This was also supported by Herzka \& Holt (2000), who stated that the high basal metabolism of endotherms probably results in a tissuespecific turnover rate that does not occur in ectotherms. However, results of the half-lives for the 3 types of grass carp tissue in the present study demonstrated that different turnover rates of the nitrogen isotope substantially varied between different fish tissues. Meanwhile, estimation based on the time and 
growth models showed that nitrogen turnover rates increased following the rank of gill $<$ muscle $<$ liver owing to the variations in enzyme systems and biochemical components between the various tissues of grass carp (Fig. 1). This is consistent with other reports in fish that showed that liver generally showed faster isotopic turnover rates than other tissues, such as muscle, heart, and cartilage (MacNeil et al. 2006, Tarboush et al. 2006, Guelinckx et al. 2007, Buchheister \& Latour 2010). As a result of the different nitrogen isotopic turnover rates, liver had the shortest half-life ( $29.9 \mathrm{~d}$ or 1.18-fold increase in mass for timeand growth-base models, respectively) compared to other tissues, suggesting the greatest potential to indicate the most recent change in dietary isotopes. Conversely, it appears that muscle and gill respond relatively more slowly to the changes in the isotopic composition of the diet (Tables $2 \& 3$ ). No significant differences in the nitrogen stable isotope composition for the 3 types of grass carp tissues in the control group were observed during the experiment, confirming the assumption that the fish had been in an isotopically steady state with the constant supply of control feed at the start of experiment.

The nitrogen stable isotope turnover rates of the 3 types of grass carp tissue were significantly higher than those predicted by growth alone (Figs. $2 \& 3$ ), which indicates that the tissue turnover might be attributable to both tissue replacement in the form of metabolism $(m)$ and net tissue increase in the form of growth $(k)$. Metabolic contributions to nitrogen isotopic turnover reached approximately $70-77 \%$ and $39-47 \%$ for liver and muscle, respectively, while $86-90 \%$ contribution of growth to nitrogen isotopic turnover was strongly correlated with less metabolic activity of gill, and reflected that growth played a more important role in the long-term isotopic turnover of gill (Tables $2 \& 3$ ). Such results indicate that metabolism is not always negligible in the isotope turnover of fish tissue (Herzka \& Holt 2000, Marcogliese 2001, Harvey et al. 2002). Similar results were also reported for whitefish Coregonus lavaretus (Perga \& Gerdeaux 2005), juvenile mummichogs Fundulus heteroclitus (Logan et al. 2006), and juvenile sand goby Pomatoschistus minutus (Guelinckx et al. 2007).

Previous studies have demonstrated that the discrepancy in turnover rates between tissues is mainly driven by variable metabolic contributions to the isotopic turnover process (Arneson \& MacAvoy 2005, MacAvoy et al. 2006). The relative importance of metabolism versus growth in nitrogen isotopic turnover is determined by bioenergetic allocations. The faster the metabolism, the quicker turnover rate, and therefore the shorter the half-life of the tissue (MacAvoy et al. 2005). Such correlation was well confirmed by the results of the present experiment. Another factor influencing nitrogen isotopic turnover rates is the different biochemical composition of tissues. The relative abundance of amino acids in the various tissues differs. The isotopic composition of essential amino acids exhibits little change during assimilation. However, amino acids that are wholly synthesized or at least partly modified may undergo shifts in $\delta^{15} \mathrm{~N}$ with varying magnitude depending on the biosynthetical pathway (Pinnegar \& Polunin 1999, Guelinckx et al. 2007). Liver protein is known to have a greater proportion of essential amino acids, which might explain the higher observed $\delta^{15} \mathrm{~N}$ values for liver (Kurle \& Worthy 2002, McClelland \& Montoya 2002).

Nitrogen isotopic fractionation might differ significantly among species and tissues. Based on a mathematical model, Martínez del Rio \& Wolf (2005) predicted that $\delta^{15} \mathrm{~N}$ values of growing organisms were significantly lower than those of non-growing organisms, and $\delta^{15} \mathrm{~N}$ values decreased as the ratio of incorporated nitrogen in tissues increased. In the present study, the nitrogen isotopic fractionation showed significant differences between the 3 tissues, which is consistent with results from other reports (Sweeting et al. 2007, Buchheister \& Latour 2010). The principal factor that might explain the differentiation in $\delta^{15} \mathrm{~N}$ between tissues is the variation in amino acid profiles for specific tissues. The $\delta^{15} \mathrm{~N}$ of different amino acids generally varies significantly (McClelland \& Montoya 2002, Fogel \& Tuross 2003), resulting in subsequent differences in isotopic fractionation among tissues (Howland et al. 2003). Pinnegar \& Polunin (1999) also reported that amino acid profiles influenced the fractionation of various tissues. The intertissue variation in $\delta^{15} \mathrm{~N}$ in the present study suggests that such a phenomenon is possibly common in fish.

Acknowledgements. The work described in this paper was funded by a grant from the National Basic Research Program of China ('973' Program, Project No. 2009CB118706), the Program for New Century Excellent Talents in University (NCET110466), and the 111 project, China Ministry of Education.

\section{LITERATURE CITED}

Arneson LS, MacAvoy SE (2005) Carbon, nitrogen and sulfur diet-tissue discrimination in mouse tissues. Can J Zool 83:989-995

> Bosley KL, Witting DA, Chambers RC, Wainright SC (2002) Estimating turnover rates of carbon and nitrogen in recently metamorphosed winter flounder Pseudopleuro- 
nectes americanus with stable isotopes. Mar Ecol Prog Ser 236:233-240

> Buchheister A, Latour RJ (2010) Turnover and fractionation of carbon and nitrogen stable isotopes in tissues of a migratory coastal predator, summer flounder (Paralichthys dentatus). Can J Fish Aquat Sci 67:445-461

Fisk AT, Sash K, Jaerz J, Palmer W, Carroll JP, MacNeil MA (2009) Metabolic turnover rates of carbon and nitrogen stable isotopes in captive juvenile snakes. Rapid Commun Mass Spectrom 23:319-326

Fogel ML, Tuross N (2003) Extending the limits of paleodietary studies in humans with compound specific carbon isotope analysis of amino acids. J Archaeol Sci 30: 535-545

Fry B (2006) Stable isotope ecology. Springer, New York, NY

> Gannes LZ, O'Brien DM, Del Rio CM (1997) Stable isotopes in animal ecology: assumptions, caveats, and a call for more laboratory experiments. Ecology 78:1271-1276

Gao QF, Paul KSS, Lin GH, Chen SP, Cheung SG (2006) Stable isotope and fatty acid evidence for uptake of organic waste by green-lipped mussels Perna viridis in a polyculture fish farm system. Mar Ecol Prog Ser 317: 273-283

Gao QF, Wang YS, Dong SL, Sun ZL, Wang F (2011) Absorption of different food sources by sea cucumber Apostichopus japonicus (Selenka) (Echinodermata: Holothuroidea): evidence from carbon stable isotope. Aquaculture 319:272-276

Guelinckx J, Maes J, Van Den Driessche P, Geysen B, Dehairs F, Ollevier F (2007) Changes in $\delta^{13} \mathrm{C}$ and $\delta^{15} \mathrm{~N}$ in different tissues of juvenile sand goby Pomatoschistus minutus: a laboratory diet-switch experiment. Mar Ecol Prog Ser 341:205-215

Harvey CJ, Hanson PC, Essinton TE, Brown PB, Kitchell JF (2002) Using bioenergetic models to predict stable isotope ratios in fishes. Can J Fish Aquat Sci 59:115-124

Herzka SZ, Holt GJ (2000) Changes in isotopic composition of red drum (Sciaenops ocellatus) larvae in response to dietary shifts: potential applications to settlement studies. Can J Fish Aquat Sci 57:137-147

$>$ Herzka SZ, Holt SA, Holt GJ (2001) Documenting the settlement history of individual fish larvae using stable isotope ratios: model development and validation. J Exp Mar Biol Ecol 265:49-74

> Hesslein RH, Haallard KA, Ramlal P (1993) Replacement of sulfur, carbon and nitrogen in tissue of growing broad whitefish (Coregonus nasus) in response to a change in diet traced by $\delta^{34} \mathrm{~S}, \delta^{13} \mathrm{C}, \delta^{15} \mathrm{~N}$. Can J Fish Aquat Sci 50:2071-2076

Hobson KA, Sirois J, Gloutney ML (2000) Tracing nutrient allocation to reproduction with stable isotopes: a preliminary investigation using colonial waterbirds of Great Slave Lake. Auk 117:760-774

Howland MR, Corr LT, Young SMM, Jones V and others (2003) Expression of the dietary isotope signal in the compound-specific $\delta^{13} \mathrm{C}$ values of pig bone lipids and amino acids. Int J Osteoarchaeol 13:54-65

> Jones JI, Waldron S (2003) Combined stable isotope and gut contents analysis of food webs in plant-dominated, shallow lakes. Freshw Biol 48:1396-1407

> Karlsson J, Joneson A, Meili M, Jansson M (2004) $\delta^{15} \mathrm{~N}$ of zooplankton species in subarctic lakes in northern Sweden: effects of diet and trophic fractionation. Freshw Biol 49:526-534

Kurle CM, Worthy GAJ (2002) Stable nitrogen and carbon isotope ratios in multiple tissues of the northern fur seal Callorhinus ursinus: implications for dietary and migratory reconstructions. Mar Ecol Prog Ser 236:289-300

Logan J, Haas H, Deegan L, Gaines E (2006) Turnover rates of nitrogen stable isotopes in the salt marsh mummichog, Fundulus heteroclitus, following a laboratory diet switch. Oecologia 147:391-395

MacAvoy SE, Macko SA, Arnesion LS (2005) Growth versus metabolic tissue replacement in mouse tissues determined by stable carbon and nitrogen isotope analysis. Can J Zool 83:631-641

> MacAvoy SE, Arneson LS, Bassett E (2006) Correlation of metabolism with tissue carbon and nitrogen turnover rate in small mammals. Oecologia 150:190-201

MacNeil MA, Skomal GB, Fisk AT (2005) Stable isotopes from multiple tissues reveal diet switching in sharks. Mar Ecol Prog Ser 302:199-206

> MacNeil MA, Drouilard KG, Fisk AT (2006) Variable uptake and elimination of stable nitrogen isotopes between tissues in fish. Can J Fish Aquat Sci 63:345-353

Marcogliese DJ (2001) Pursuing parasites up the food chain: implications of food web structure and function on parasite communities in aquatic systems. Acta Parasitol 46: 82-93

Martínez del Rio C, Wolf BO (2005) Mass balance models for animal isotopic ecology. In: Starck MA, Wang T (eds) Physiological and ecological adaptations to feeding in vertebrates. Science Publishers, Enfield, NH, p 141-174

Maruyama A, Yamada Y, Rusuwa B, Yuma M (2001) Change in stable nitrogen isotope ratio in the muscle tissue of a migratory goby, Rhinogobius sp., in a natural setting. Can J Fish Aquat Sci 58:2125-2128

> McClelland JW, Montoya JP (2002) Trophic relationships and the nitrogen isotopic composition of amino acids in plankton. Ecology 83:2173-2180

- McCutchan JH Jr, Lewis WM, Kendall C, McGrath CC (2003) Variation in trophic shift for stable isotope ratios of carbon, nitrogen, and sulfur. Oikos 102:378-390

McIntyre PB, Flecker AS (2006) Rapid turnover of tissue nitrogen of primary consumers in tropical freshwaters. Oecologia 148:12-21

Minagawa M, Wada E (1984) Stepwise enrichment of ${ }^{15} \mathrm{~N}$ along food chains: further evidence and the relationship between $\delta^{15} \mathrm{~N}$ and animal age. Geochim Cosmochim Acta 48:1135-1140 doi:10.1016/0016-7037(84)90204-7

MOAC (Ministry of Agriculture, China) (2011) China fisheries yearbook, 2010. China Agriculture Publisher, Beijing

> Murchie KJ, Power M (2004) Growth- and feeding-related isotopic dilution and enrichment patterns in young-ofthe-year yellow perch (Perca flavescens). Freshw Biol 49: $41-54$

> Overmyer JP, MacNeil MA, Fisk AT (2008) Fractionation and metabolic turnover of carbon and nitrogen stable isotopes in black fly larvae. Rapid Commun Mass Spectrom 22:694-700

> Perga ME, Gerdeaux D (2005) 'Are fish what they eat' all year round? Oecologia 144:598-606

> Persaud AD, Dillon PJ, Molot LA, Hargan E (2012) Relationships between body size and trophic position of consumers in temperate freshwater lakes. Aquat Sci 74: 203-212

Peterson BJ, Fry B (1987) Stable isotopes in ecosystem studies. Annu Rev Ecol Evol Syst 18:293-320

Phillips DL, Gregg JW (2003) Source partitioning using stable isotopes: coping with too many sources. Oecologia 
136:261-269

Pinnegar JK, Polunin NVC (1999) Differential fractionation of $\delta^{13} \mathrm{C}$ and $\delta^{15} \mathrm{~N}$ among fish tissues: implications for the study of trophic interactions. Funct Ecol 13:225-231

> Post DM (2002) Using stable isotopes to estimate trophic position: models, methods and assumptions. Ecology 83: 703-718

Reich KJ, Bjorndal KA, Martínez del Rio C (2008) Effects of growth and tissue type on the kinetics of ${ }^{13} \mathrm{C}$ and ${ }^{15} \mathrm{~N}$ incorporation in a rapidly growing ectotherm. Oecologia 155:651-663

Sakano H, Fujiwara E, Nohara S, Ueda H (2005) Estimation of nitrogen stable isotope turnover rate of Oncorhynchus nerka. Environ Biol Fishes 72:13-18

SPSS Inc. (2008) SPSS 16.0 student version for Windows. Prentice Hall, Upper Saddle River, NJ

Sulak KJ, Berg JJ, Randall M (2012) Multiple stable isotopes define feeding ecology of the Gulf of Mexico sturgeon, Acipenser oxyrinchus desotoi. Environ Biol Fishes 95: 237-258

Sun ZL, Gao QF, Dong SL, Shin PKS, Wang F (2012) Estimates of carbon turnover rates in the sea cucumber Apostichopus japonicus (Selenka) using stable isotope analysis: the role of metabolism and growth. Mar Ecol Prog Ser 457:101-112

Suring E, Wing SR (2009) Isotopic turnover rate fractionation in multiple tissues of red rock lobster (Jasus edwardsii) and blue cod (Parapercis colias): consequences for ecological studies. J Exp Mar Biol Ecol 370:56-63

Editorial responsibility: Kenneth Black,

Oban, UK
Sweeting CJ, Jennings S, Polunin NVC (2005) Variance in isotopic signatures as a descriptor of tissue turnover and degree of omnivory. Funct Ecol 19:777-784

> Sweeting CJ, Barry J, Barnes C, Polunin NVC, Jennings S (2007) Effects of body size and environment on diettissue $\delta^{15} \mathrm{~N}$ fractionation in fishes. J Exp Mar Biol Ecol 340:1-10

Tarboush RA, MacAvoy SE, Macko SA, Connaughton V (2006) Contribution of catabolic tissue replacement to the turnover of stable isotopes in Danio rerio. Can J Zool 84: 1453-1460

Tieszen LL, Boutton TW, Tesdahl KGC, Slade NA (1983) Fractionation and turnover of stable carbon isotopes in animal tissues: implications for $\delta^{13} \mathrm{C}$ analysis of diet. Oecologia 57:32-37

Tominaga O, Uno N, Seikai T (2003) Influence of diet shift from formulated feed to live mysids on the carbon and nitrogen stable isotope ratio $\delta^{13} \mathrm{C}$ and $\delta^{15} \mathrm{~N}$ in dorsal muscles of juvenile Japanese flounders, Paralichthys olivaceus. Aquaculture 218:265-276

Vanderklift MA, Ponsard S (2003) Sources of variation in consumer-diet $\delta^{15} \mathrm{~N}$ enrichment: a meta-analysis. Oecologia 136:169-182

Vander Zanden MJ, Hulshof M, Ridgway MS, Rasmussen JB (1998) Application of stable isotope techniques to trophic studies of age-0 smallmouth bass. Trans Am Fish Soc 127:729-739

Zar JH (1999) Biostatistical analysis. Prentice Hall, Upper Saddle River, NJ

Submitted: November 12, 2012; Accepted: February 4, 2013 Proofs received from author(s): March 13, 2013 